\title{
MENINGKATKAN HASIL BELAJAR SISWA DENGAN MENGGUNAKAN MODEL PEMBELAJARAN MAKE A MATCH PADA MATA PELAJARAN IPS DI KELAS V SD NEGERI 106163 BANDAR KLIPPA
}

\author{
Masta Ginting \\ Surel : mastaginting01@gmail.com
}

\begin{abstract}
ABSTRAK
Penelitian ini bertujuan untuk meningkatkan hasil belajar siswa. Penelitian ini menggunakan desain PTK. Subjek dalam penelitian ini berjumlah 25 orang. Berdasarkan hasil penelitian pada saat tes awal tingkat ketuntasan klasikal sebanyak 5 orang siswa (20\%) sedangkan sebanyak 20 orang siswa ( $80 \%$ ) belum mendapat nilai tuntas dan rata-rata klasikal 46,42. Pada siklus I sebanyak 10 orang siswa (40\%) mendapat nilai tuntas dan sebanyak 15 orang siswa (60\%) belum mendapat nilai tuntas dan rata-rata klasikal 60,01. Pada siklus II sebanyak 21 orang siswa $(84 \%)$ mendapat nilai tuntas, sedangkan sebanyak 4 orang siswa (16\%) belum mendapat nilai tuntas, dengan nilai rata-rata klasikal 86,01.
\end{abstract}

Kta Kunci : Hasil Belajar, IPS, Make A Match

\section{PENDAHULUAN}

Pendidikan IPS mempunyai

peran dalam mengubah tingkah laku anak didik agar menjadi manusia dewasa yang hidup mandiri dan sebagai anggota masyarakat yang berkarakter dalam lingkungan masyarakat. Pendidikan tidak hanya mencakup pengembangan intelektualitas saja, akan tetapi lebih ditekankan pada proses pembinaan kepribadian anak didik secara menyeluruh sehingga anak menjadi lebih dewasa dalam bersikap dan berprilaku.

Berdasarkan Identifikasi masalah di atas, maka masalah dalam penelitian ini dibatasi pada "Meningkatkan hasil belajar siswa dengan menggunakan model pembelajaran make a match pada mata pelajaran IPS materi pokok
Peristiwa Menjelang Kemerdekaan di Kelas V SD Negeri 106163 Bandar Klippa T.A 2015/2016".

Adapun tujuan dari penelitian ini adalah untuk meningkatkan hasil belajar siswa dengan menggunakan model pembelajaran make a match pada mata pelajaran IPS materi pokok Peristiwa Menjelang Kemerdekaan di Kelas V SD Negeri 106163 Bandar Klippa T.A 2015/2016.

Manfaat yang diambil dari hasil penelitin ini adalah:

1. Bagi siswa, sebagai bahan masukan bagi siswa dalam meningkatkan hasil belajar siswa.

2. Bagi guru, sebagai bahan masukan dalam meningkatkan keterampilan guru dalam mengembangkan model pembelajaran kooperatif model make a macth dalam mata pelajaran IPS. 
3. Bagi sekolah, hasil penelitian ini dapat menjadi referensi sebagai masukan dan evaluasi guna meningkatkan mutu dan kuatilas pendidikan di SD Negeri 106163 Bandar Klippa

4. Bagi peneliti, dapat mengembangkan wawasan dan pengalaman peneliti dalam peningkatan kualitas pembelajaran

5. Bagi peneliti lain, menjadi referensi sebagai masukan untuk perbandingan bagi peneliti lain yang meneliti permasalahan yang sama.

Rendahnya hasil belajar siswa menjadi gambaran bahwa pembelajaran yang dilakukan selama ini belum memperoleh hasil yang maksimal dan tidak kreatif. Siswa hanya mendengarkan penjelasan dari guru dengan mencatatnya kedalam buku catatan. Sedangkan partisipasi siswa dalam pembelajaran jarang sekali diperhatikan.

Untuk memperbaiki hal tersebut perlu disusun suatu pendekatan dalam pembelajaran yang lebih efektif sehingga siswa "tertantang" untuk belajar yaitu dengan menggunakan model make a match. Model pembelajaran ini dapat memotivasi siswa dalam belajar karena penekanan dari penggunaan teknik make a match lebih menitik beratkan peran aktif siswa selama pembelajaran dimana tuntutan dari model ini adalah siswa merupakan subjek belajar.

Teknik make a match sendiri yaitu melatih siswa menguasai materi dengan cara memasangkan antara pertanyaan dan jawaban. Dimana prinsipnya, siswa harus mempunyai pengetahuan tentang materi yang akan diajarkan terlebih dahulu. Baru setelah itu guru dapat menggunakan model pembelajaran make a match atau mencari pasangan.

\section{METODE PENELITIAN}

Penelitian ini dilaksanakan di SD Negeri 106163 Bandar Klippa T.A 2015/2016. Sekolah ini mempunyai luas tanah $1.667 \mathrm{~m}^{2}$. Mempunyai 7 ruang kelas yang berukuran $\pm 49 \mathrm{~m}^{2}$. Sarana lainnya yang mendukung adalah perpustakaan, kantor kepala sekolah sekaligus ruang guru, ruang UKS, toilet, gudang, kantin, rumah dinas.

Penelitian ini dilaksanakan di kelas V SD Negeri 106163 Bandar Klippa T.A 2015/2016. Sebagai subjek dalam penelitian ini adalah siswa kelas V SD Negeri 106163 Bandar Klippa T.A 2015/2016 sebanyak 25 orang. Objek penelitian tindakan kelas ini adalah penggunaan model pembelajaran make a match untuk meningkatkan hasil belajar siswa pada pelajaran IPS materi peristiwa menjelang kemerdekaan.

Guna meningkatkan partisipasi dan keaktifan siswa menggunakan make a match, langkah-langkah yang dapat dilakukan guru yaitu menyiapkan beberapa kartu yang berisi beberapa konsep dan jawaban. Setiap siswa nantinya akan dibagikan kartu yang dipegang. Selanjutnya, guru 
mengarahkan agar setiap siswa mencari pasangan yang mempunyai kartu yang cocok dengan kartunya, bagi siswa yang dapat mencocokkan kartunya sebelum batas waktu diberi poin sesuai dengan kriteria yang ditentukan. Selanjutnya guru membagikan kembali kartu yang berbeda kepada seluruh siswa sampai seluruh siswa mendapatkan kartunya masing-masing. Diakhir pertemuan guru bersama dengan siswa memberikan kesimpulan terhadap materi pelajaran yang telah dipelajari dan membuat catatan-catatan penting yang harus dipahami siswa.

Hipotesis yang diajukan dalam penelitian ini adalah dengan menggunakan model pembelajaran kooperatif make a match dapat Meningkatkan Hasil Belajar Siswa pada mata pelajaran IPS materi pokok Peristiwa Menjelang Kemerdekaan di Kelas V SD Negeri 106163 Bandar Klippa T.A 2015/2016.

\section{HASIL DAN PEMBAHASAN Deskripsi Data Awal Siswa (Tes Awal)}

Langkah awal sebelum melakukan tindakan penelitian adalah dengan melakukan observasi terhadap siswa. Observasi yang dilakukan untuk mengetahui masalah yang dialami oleh siswa dalam pelajaran IPS materi peristiwa menjelang kemerdekaan. Tes Awaltersebut diberikan kepada siswa kelas VSD Negeri 106163 Bandar Klippa T.A 2015/2016.
Soal tes awal yang diberikan dalam bentuk pilihan berganda sebanyak 20 soal. Untuk memberikan nilai nilai kepada siswa terlebih dahulu dilakukan penskoran. Hal ini bertujuan agar hasil penelitian menjadi objektif. Dengan skor tertinggi 20 dan nilai 100. Nilai ketuntasan untuk pelajaran IPS adalah 70. Berdasarkan hasil penelitian di peroleh nilai tes awal sebagai berikut:

Dari keseluruhan siswa kelas $\mathrm{V}$ yg berjumlah 25 orang, hanya 5 orang $(20 \%)$ siswa yang tuntas dan sebanyak 20 orang (80\%) tidak tuntas. Hal ini membuktikan bahwa hasil belajar siswa kelas $\mathrm{V}$ secara klasikal belum tuntas karena belum mencapai $80 \%$ tingkat ketuntasan klasikal. Hasil ketuntasan belajar siswa dapat dilihat pada grafik berikut ini:

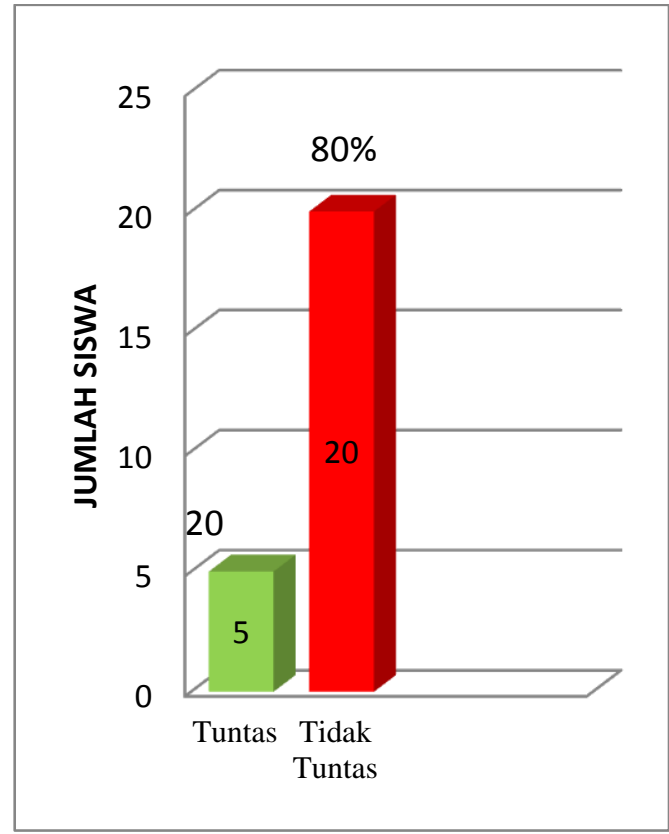

Grafik Persentase Ketuntasan Belajar Klasikal Pada Tes Awal 
Berdasarkan grafik di atas, jelaslah bahwa siswa kelas V SD Negeri 106163 Bandar Klippa T.A 2015/2016 sebanyak 80\% mengalami ketidaktuntasan dalam belajar.

\section{Deskripsi Hasil Penelitian Siklus I}

1. Tahap Perencanaan Tindakan

2. Tahap Pelaksanaan Tindakan

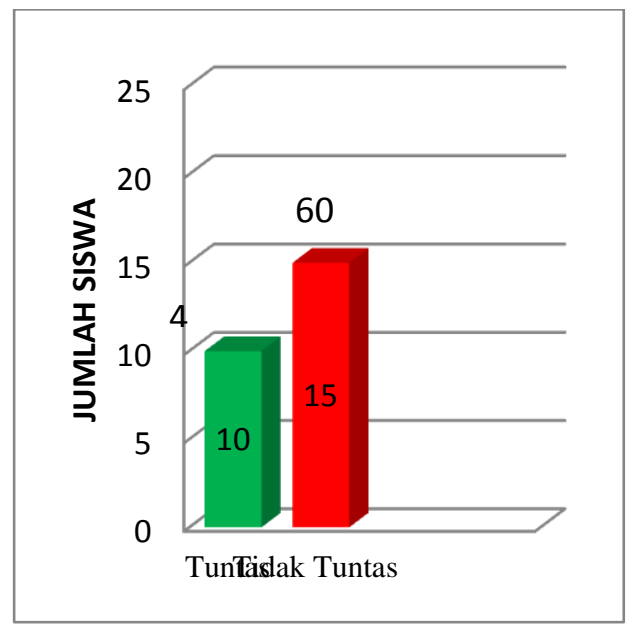

Grafik Persentase Ketuntasan Belajar Klasikal Pada Post Test Siklus I

Hasil ketuntasan belajar klasikal pada post test siklus II dapat dilihat pada grafik berikut ini:

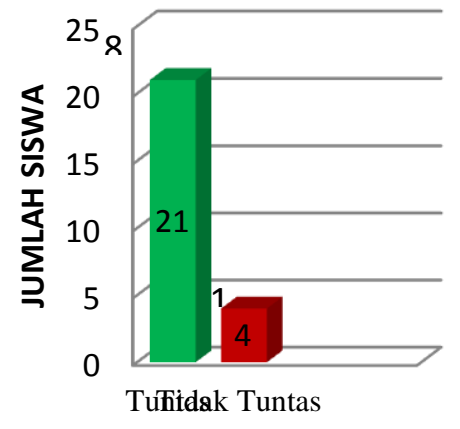

Grafik Persentase Ketuntasan Belajar Klasikal Pada Post Test Siklus II

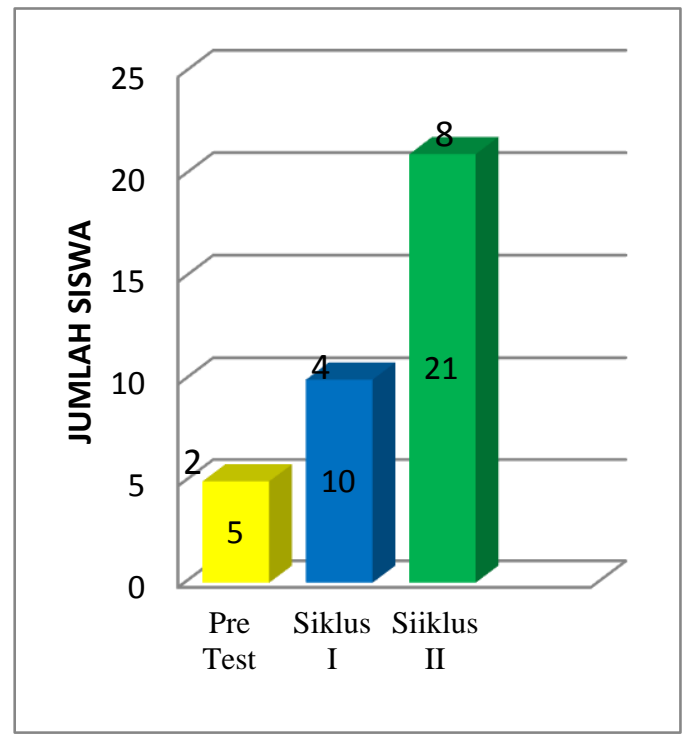

Grafik Grafik Ketuntasan Belajar Pada Tes Awal, Post Test Siklus I dan Siklus II

\section{Pembahasan Hasil Penelitian}

Berdasarkan analisis data yang telah dilakukan pada siklus I dan II, maka dapat dijabarkan bahwa hasil tes awal yang diikuti oleh 25 siswa kelas VSD Negeri 106163 Bandar Klippa T.A 2015/2016 pada pelajaran IPS materi peristiwa menjelang kemerdekaan nilai tertingginya adalah 86,7 dan terendah 26,7. Dari 25 siswa hanya 5 orang yang mengalami ketuntasan belajar atau sebesar $20 \%$, sebanyak 20 siswa atau sebesar $80 \%$ siswa tidak tuntas dalam belajar. Dan nilai rata-rata klasikal sebesar 46,42. Tingkat ketuntasan belajar klasikalnya sebesar 20\%. Hal tersebut masih dibawah $80 \%$ ketuntasan yang diharapkan.

Setelah diberi tindakan pada siklus I dengan menggunakan model pembelajaran make a match pada pelajaran IPS materi peristiwa 
menjelang kemerdekaan, diperoleh nilai tertinggi 93,35 dan terendah 33,35 . Sebanyak 10 siswa atau sebesar $40 \%$ mengalami ketuntasan belajar, sebanyak 15 siswa atau sebesar $60 \%$ tidak tuntas dalam belajar. Dan nilai rata-rata klasikalnya 60,01. Ketuntasan belajar klasikalnya 40\%. Jika dilihat dari hasil Tes Awal terjadi peningkatan jumlah siswa yang mengalami ketuntasan belajar, akan tetapi tindakan pada siklus I belum bisa dikatakan berhasil karena masih dibawan $80 \%$ ketuntasan yang diharapkan. Hasil observasi aktivitas belajar siswa rata-ratanya sebesar 23,48 . Oleh karena itu dilakukan tindakan perbaikan pada siklus II.

Hasil analisis data pada siklus II, diperoleh nilai tertinggi 100 dan terendah 60. 21 siswa mengalami ketuntasan belajar atau sebesar $84 \%$ dan sebanyak 4 siswa atau sebesar 16\% mengalami ketidaktuntasan dalam belajar. Dengan nilai rata-rata klasikalnya 86,15. Dari data tersebut, ketuntasan belajar klasikal siswa kelas V pada pelajaran IPS tergolong sangat tinggi dan telah melebihi $80 \%$ ketuntasan yang diharapkan. Hal ini menunjukkan bahwa, terjadi peningkatan hasil belajar siswa pada siklus II. Dari hasil observasi aktivitas belajar siswa pada siklus II rata-ratanya sebesar 32 .

berdasarkan hasil penelitian ini diperoleh gambaran bahwa model pembelajaran make a match dapat meningkatkan hasil belajar siswa dalam menyelesaikan soal-soal. Hal ini disebabkan bentuk pelajaran tidak hanya dipusatkan kepada guru semata yang berperan aktif akan tetapi lebih memperhatikan keterlibatan siswa secara aktif.

Dengan demikian, maka hipotesis tindakan yang diajukan dalam penelitian ini adalah menerima hipotesis yang menyatakan dengan menggunakan model pembelajaran make a match dapat meningkatkan hasil belajar siswa pada mata pelajaran IPS materi peristiwa menjelang kemerdekaan di kelas $\mathrm{V}$ SD Negeri 106163 Bandar Klippa T.A 2015/2016.

\section{KESIMPULAN}

Berdasarkan analisis data dan pembahasan hasil penelitian, diperoleh kesimpulan sebagai berikut:

1. Dari hasil Tes Awal diketahui dari 25 siswa pada saat diberikan pre test tingkat ketuntasan klasikal siswa kelas V sebanyak 5 orang siswa (20\%) sedangkan sebanyak 20 orang siswa $(80 \%)$ belum mendapat nilai tuntas. Dengan kategori mendapat nilai rendah (20-39) sebanyak 11 orang siswa (44\%), mendapat nilai sedang (40-59) sebanyak 8 orang siswa (32\%), mendapat nilai tinggi (60-79) sebanyak 5 siswa (20\%), dan sangat tinggi (>80) sebanyak 1 orang siswa (4\%) dengan nilai rata-rata klasikal 46,42.

2. Pada siklus I sebanyak 10 orang siswa (40\%) mendapat nilai tuntas dan 15 orang siswa $(60 \%)$ belum mendapat nilai tuntas. 
Dengan perincian kategori nilai rendah (20-39) sebanyak 2 siswa $(8 \%)$, mendapat nilai sedang (4059) sebanyak 10 orang siswa (40\%), mendapat nilai tinggi (6079) sebanyak 7 orang siswa (28\%), dan nilai sangat tinggi (>80) sebanyak 6 siswa $(24 \%)$ dengan nilai rata-rata klasikal 60,01.

3. Pada siklus sebanyak 21 orang siswa $(84 \%)$ yang mendapat nilai tuntas sedangkan sebanyak 4 orang siswa (16\%) belum mendapat nilai tuntas. Dengan perincian tidak ditemukan siswa (0\%) yang mendapat nilai rendah (20-39), tidak ditemukan yang mendapat nilai sedang (40-59), mendapatkan nilai tinggi (60-79) sebanyak 5 orang siswa (20\%), dan yang mendapat nilai sangat tinggi (>80) sebanyak 20 orang siswa $(80 \%)$ dengan nilai ratarata klasikal 86,15. Bila dibandingkan dengan nilai post test pada siklus I maka dapat dikatakan terdapat peningkatan hasil belajar siswa pada siklus II sebesar $84 \%-40 \%=44 \%$, dengan demikian maka dapat dikatakan terjadi peningkatan hasil belajar siswa dari siklus I ke siklus II.

4. Berdasarkan hasil observasi aktivitas belajar siswa pada siklus I ditemukan $69,44 \%$ persentase hasil belajar siswa, dan pada siklus II sebesar $88,88 \%$ tingkat persentase hasil belajar siswa. Dengan demikian dapat disimpulkan terdapat peningkatan aktivitas belajar siswa dari siklus I ke siklus II.

5. Hipotesis yang menyatakan dengan menggunakan model pembelajaran make a match dapat meningkatkan hasil belajar siswa pada mata pelajaran IPS materi peristiwa menjelang kemerdekaan di kelas V SD negeri 106163 Bandar Klippa.

Adapun saran dalam penelitian ini ditujukan kepada:

1. Kepala sekolah SD Negeri 106163 Bandar Klippa

Agar lebih memperhatikan kegiatan pembelajaran yang dilakukan guru sehingga hasil belajar yang didapat siswa melalui proses pembelajaran dapat lebih optimal.

2. Guru SD Negeri 106163 Bandar Klippa

Agar lebih meningkatkan keterampilan mengajarnya dan memahami berbagai model pembelajaran yang dapat diterapkan dalam proses belajar, sehingga siswa selalu termotivasi dalam belajar dan hasil belajar dapat meningkat.

3. Bagi siswa SD Negeri 106163 Bandar Klippa

Agar lebih termotivasi dan aktif serta kreatif dalam kegiatan belajar di sekolah.

4. Bagi peneliti lain

Agar lebih mengoptimalkan penelitiannya dengan menggunakan berbagai macam model pembelajaran, strategi, 
pendekatan, media serta tehnik yang bervariasi.

\section{DAFTAR RUJUKAN}

Aqib, Zainal, dkk. 2010. Penelitian

Tindakan Kelas. Bandung: Yrama Widya.

Bungs. 2012. Model Pembelajaran Make And Match. http://wbungs.blogspot.co.id/20 12/07/model-pembelajaranmake-and-match. Diakses Minggu, 15 Juli 2012.

Dewi, Rosmala. 2010. Penelitian Tindakan Kelas. Medan: Paska Sarjana Unimed.

Dimyati,dkk. 2013. Belajar \& Pembelajaran. Jakarta: Rineka Cipta.

Djamarah, Syaiful Bahri. 2011. Psikologi Belajar. Jakarta: Rineka Cipta.

Hartono, Rudi, 2013. Ragam Model Mengajar Yang Mudah Diterima Murid. Jakarta: Diva Press.

Jihad, Asep, dkk. 2012. Evaluasi Pembelajaran. Yogyakarta: Multi Pressindo.

Purwanto. 2011. Evaluasi Hasil Belajar. Yogyakarta Pustaka Pelajar.

Rusman. 2010. Model-Model Pembelajaran. Jakarta: Kencana.

Shoimin, Aris. 2014. 68 Model Pembelajaran Inovatif Dalam Kurikulum 2013. Yogyakarta: Ar-ruzz Media.
Solihatin, Etin, dkk. 2008. Cooperative Learning. Jakarta: Bumi Aksara.

Slameto. 2010. Belajar dan FaktorFaktor yang Mempengaruhinya. Jakarta: Rineka Cipta.

Sudjana, Nana. 2010. Penilaian Hasil Proses Belajar Mengajar. Bandung: Remaja Rosdakarya.

Tarmizi. 2008. Pembelajaran Kooperatif Make A Match. https://tarmizi.wordpress.com/2 008/12/03/pembelajarankooperatif-make-a-match/. Diakses 3 Desember 2008.

Tim Tunas Karya Guru, 2013. Ilmu Pengetahuan Sosial. Jakarta: Duta.

Trianto. 2011. Model Pembelajaran Terpadu. Jakarta: Kencana.

Trianto, 2012. Mendesain Model Pembelajaran InovatifProgresif. Jakarta: Kencana Prenada Media Group. 